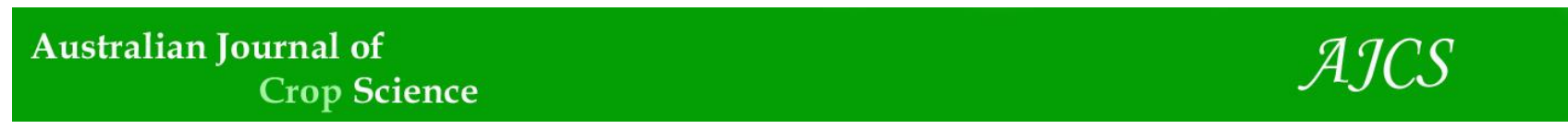

AJCS 12(10):1626-1632 (2018)

ISSN:1835-2707

doi: 10.21475/ajcs.18.12.10.p1202

\title{
The chia (Salvia hispanica): past, present and future of an ancient Mexican crop
}

\author{
Anacleto Sosa-Baldivia ${ }^{1,3}$, Guadalupe Ruiz-lbarra², Raúl René Robles de la Torre ${ }^{3}$, Reyna Robles López ${ }^{3}$, \\ Aurora Montufar López ${ }^{4}$
}

${ }^{1}$ Nutrilite S de RL de CV. Av. México \#8. Rancho el Petacal, Municipio de Tolimán Jalisco, México

${ }^{2}$ Instituto Tecnológico José Mario Molina Pasquel y Henriquez campus Tamazula, Tamazula de Gordiano Jalisco, México

${ }^{3}$ Instituto Politécnico Nacional, CIBA-IPN, Unidad-Tlaxcala, Ex-Hacienda de San Juan Molino, Km 1.5 Carretera

Estatal Tecuexcomac-Tepetitla, Tepetitla, Tlaxcala, México

${ }^{4}$ Instituto Nacional de Antropología e Historia (INAH), DF, México

*Corresponding author: anacleto.sosa@amway.com

\begin{abstract}
The history of chia (Salvia hispanica L.) as a domesticated crop presents many contradictions. Almost 4,500 years ago in Mesoamerica, chia was used as food and medicine. However, just only in three centuries, chia became a forgotten crop and remained an unknown crop for many years. Considering this issue, the main objective of this review was to testify the importance and history of chia as a Mexican ancestral crop. Chia along with corn and bean were keys for the nutrition of the ancient habitants in Mesoamerica. It has been reported that Spanish domination brought a massive reduction of the native population of Mexico down to $5 \%$ (from 22 million of native people at 1520 to 1 million at 1620). These two facts caused the use of chia to diminish and almost disappear. The chia crop was rescued thanks to a small group of farmers in Jalisco, Guerrero, and Puebla. Around 1990, they developed a crop of chia and preserved the tradition of their use. Today its value as crop and food is so high and their cultivation and consumption are currently takes place in 30 countries. The chia's demand will be increased up to 239 $\%$ by 2020 and its sales are expected to reach 1.2 billion dollars. It is clear that after 500 years of lethargy chia will be the Sleeping Beauty of Mexico.
\end{abstract}

Key words: chia, polyunsaturated fatty acids Omega-3, Proteins, Fiber, nutrition.

Abbreviations: PUFAS_polyunsaturated fatty acids; B.C._before Christ; A.C._after Christ; USDA_ Department of Agriculture of the United States; USA_United States of America; Co._company.

\section{Introduction}

Although the ancient people of Mesoamerica have used chia (Salvia hispanica L.) as a food and medicine since 4,500 years ago, starting in the first decades of 16th century and in only three centuries the chia crop was almost become an unknown specie. According to Ayerza and Coates (2006), this happened because the Spaniards banned its cultivation; however, there is not enough information to support this claim (Hernandez and León 1994). The reduction in consumption of chia in Mexico has several origins, but the primary causes were: (1) the decline of Mexican population or Mexicas (2) the replacement of its cultivated area by plant and animal species introduced from Europe; and (3) the diet modification as result of availability of new foods. The damage caused by the Spanish domination was so extensive, that after cultivating 30,000 ha of chia in 1550 , this area decreased to a few hectares in 1810 (Sosa et al., 2017a). The Spaniards who colonized Mexico chosen valleys with land and water, and they had a scarce interest in mountainous zones. This allowed the chia species be survived in some locations of Mexico (Cahill, 2003). After the independence
(1810) it started growing again, and by 1932 the Ministry of Agriculture reported that its cultivated area was 38 ha (Rulfo, 1937). Small groups of Mexican farmers from of Acatic Jalisco, Olinala Guerrero, and Chiepetlan Puebla, played a critical role for the chia arrival into the decade of 90 's of last century. By these years, it was discovered that the chia seed has a very high nutritional value; especially as a source of PUFAs (polyunsaturated fatty acids) Omega-3 ( $\omega$ 3) proteins, and fiber; therefore, it readily became an important crop. It was more sustainable and produced the cheapest and safest source of food to fulfill the primary requirements related to all these nutritional requirements. The integration of chia into the modern era began in 1991 through the research project known as Northwestern Regional Project. It was conducted in Argentina with the support of the USA government. The project expanded the cultivated area from 500 ha established in Mexico in 1994 to 370,000 ha in 13 countries in 2014, (Sosa et al., 2016). Cassiday (2017) estimated that in the next three years, the chia consumption will increase $239 \%$ annually. This is due to 
the demand of sources of PUFAs $\omega-3$, which is high and is not covered (CRN, 2014). Additionally, the chia seed is also used as a raw material to produce cosmetics, nutraceutical, supplements, processed foods and beverages (Sandoval and Paredes, 2013; Silveira and Salas, 2014). Ironically, although the chia is a Mexican ancient crop with 5,000 years old, its history was written just eleven years ago by Ayerza and Coates (2006). The research works developed by these researchers is great, but there is some literature published before 1900 that they did not consult. Recently, Sosa et al. (2016) published a work related with the importance of chia as a source of PUFAs $\omega-3$, but the paper extension did not allow conducting a detailed analysis of its history. The objective of this review was to undertake and provide an updated history of the chia as crop and food around the world.

\section{History of chia}

\section{Pre-hispanic era (3500 B.C. - 1521 A.C.)}

Since 3500 years B.C., the chia seed, would have been used as food along with corn, bean, amaranth, pumpkin and chili. All these crops were keys in the diet of Mexico and other countries of America (Gutierrez et al., 2014). Teotihuacan (100 B.C. - 600 A.C.) was presumably the first culture that used the chia seed. This affirmation is based on archaeological studies conducted in the pyramids of Teotihuacan, where the chia seeds have been found as offerings dedicated to gods (Morales et al., 2012). There are no records that chia was cultivated on Teotihuacan. It is thought that it was collected from wild plants and used for religious purposes, medicine, and to make handcrafts but not as food (de Agredos and Manzanilla, 2016). This assumption is supported by two recent archaeologicalbotanic studies conducted by Morales et al. (2012), and Vazquez-Alonso et al. (2014). Several researchers have reported that the Mayan culture (250-950 AC) used the chia seed as food (di Sapio et al., 2008; Gutierrez et al., 2014; Ullah et al., 2015; de Falco et al., 2017), but there is no hard data to support that thought. The Mayan diet consisted of plants, corn, beans, and squash (Lopez et al., 2012), and it was supplemented with potato, chili, cassava, cacao and local fruits (von Baeyer, 2010). Nevertheless, there are no records or archaeological-botanic studies to support that the Mayans used the chia seed as food. The Mexica culture (1325 - 1521 A.C.) domesticated the chia crop, and the Mendoza Codex records indicate that at beginning of 1500 , Tenochtitlan, the capital of this empire consumed between 4,000 and 15,000 ton per year of chia (Mohd et al., 2012). Nevertheless, chia was not only important for the Mexicas. There is evidence that in 1531, the Totorame culture cultivated chia in Sinaloa, Mexico (some 1,500 km NW from Tenochtitlan). The main evidence of that is found on the "Lienzo de Tlaxcala" (Tlaxcaltec war book), also known as Yaotlacuiloli (Bueno, 2010), painted by the Tlaxcaltecs warriors, who accompanied to Nuño de Guzman and its Spanish conquers in the conquest of Chiyametlán (today Chametla). It is also very well known that the Tlahuica culture cultivated chia in Morelos Mexico; according to Dubernard (1991), Cuauhnahuac (today Cuernavaca, Morelos) delivered chia as part of its tribute to the Mexica Empire. In addition, Lopez (2010) reported that in 1530, the
Mexica population of Olinala and Temalacatzingo Guerrero used the chia seed as food and medicine, and the chia oil in handcrafts.

\section{Colonial era (1550 - 1810 A.C.).}

According to Ayerza (2014) on colony times, the use of chia in Mexico declined because of the Mexicas used it in religious rituals, so the Spaniards decided to prohibit the cultivation and use of chia. However, the literature published between 1550 through 1810 does not support this hypothesis. For example, Farfan (1610) on his Medicine Treatise for the Diseases Management in Mexico recommended it to cure malnutrition and ophthalmic diseases. On the other side, Lopez (2010) reported that in 1530, the Spaniards allowed using the chia oil to manufacture handcrafts at Olinala Guerrero. The Spanish Crown granted this privilege in recognition because the inhabitants of Olinala did not resist evangelization (Tibon, 1982). By a similar quote, Hernan Cortés gave a reward to the inhabitants of Chamilpa Morelos for the unconditional support to build a Palace in Cuernavaca, Morelos, on 1537. He donated cultivable land for the production of chia. In addition, he provided an arm shield recognized by the Spanish Crown. The top part exhibits a vessel filled with chia seeds representing the Chiamilpan, a word that in Tlahuica language means: field cultivated with chia (Dubernard, 1991). The three historical facts mentioned above indicate that the chia was accepted by the Spaniards; therefore, the modern researchers really confused it with amaranth, which was considered a sacrilegious crop (Mapes, 2017). According to Sosa et al. (2017a), the main causes related to reduction of chia use were: (1) the decline of the native population of Mexico, whose crop was key for their daily diet. Gerhard (1986) reported that between 1520 and 1620 the Mexican population decreased from 22 million to 1.0 million; (2) the replacement of the area cultivated with chia by plant and animal species introduced from Europe (wheat, barley, sugar cane, cattle, sheep and other ones), (Hernández and León, 1994); and (3) the diet modification as a result of the availability of new animal and plant foods (Roman et al., 2013). To determine how these events affected the chia use is not possible. Nonetheless, the drastic reduction of the Mexican population during the first century of colonization could have caused the greatest impact. This assumption is made considering that in the regions, where the Mexican population was extinct, chia had the same destiny. There is evidence that the Totorame culture cultivated chia in Chametla Sinaloa in 1831 (Bueno, 2010), but the slavery, persecution, and diseases caused the the Totorame population drop to $1 \%$ (Rosenblat, 1945) in just 21 years of Spanish domination. So, by the end of 19th century, the Totorame culture was disappeared (Noriega, 1898), and its habitat place was occupied by white and mestizo people (Macias, 2009). As result of this, today in Chametla, there is no Totorame population and the chia crop is not cultivated. In contrast, Temalacatzingo, Guerrero was one of the few locations in Mexico where the limited presence of Spaniards allowed the population to keep the chia tradition alive. This has made it possible for generations to share information between them (Lopez, 2010). The 289 years of Spanish domination caused the use of chia to almost disappear. This fact is reflected not only as the loss of knowledge associated 
with its use, agronomic management and varieties developed (Gutierrez et al., 2014); but also the scarce literature published about chia on Mexico. According to León (1895), 805 publications of Agriculture published between 1521 and 1810, only Farfan (1610) dedicated a few lines to highlight the chia use as food and medicine in Mexico; while at an international level, the more relevant fact was its botanical classification done by Linneo (1753).

\section{Post-colony era (1810-1990 A.C.).}

The chia crop could overcome the damage caused by the Spanish domination, because some locations like Puebla, Guerrero, Morelos, Michoacán, and Jalisco in Mexico continued its cultivation. The record of operations uncovered by the NAO of China indicates that between 1719 and 1801, chia seed was exported from Mexico to Europe (Sosa and Ruiz, 2016). In 1832, the Academy of Spanish Language changed the chian term to the actual word chia (Haugen, 2009). This change standardized the use of chia among Spanish speakers, but it also caused confusion for the modern researchers, especially those who do not know about the crops of chia, chan, huazontle, amaranth, and psyllium, and commit a common mistake of calling all these crops, chia crops (Sosa et al., 2017a). The chia was used as medicine in Puebla Mexico. The AMQP (1832) in its "Primer Ensayo de Materia Médica" recommended chia as an emollient, energizing food being used for the treatment of malnutrition and ophthalmic diseases. This was later confirmed by AFRM (1846) in its "Farmacopea Mexicana". De La Llave (1833) conducted the first formal study on chia. His work included and highlighted the nutritional properties of chia. He affirmed that the chia was not native to Spain, and he suggested changing the scientific name to Salvia nezahualia or Salvia chian in order to correct this mistake. Sixteen years later, Guibourt (1849a), in the book "Natural History of Simple Drugs" wrote about the medicinal use of chia. He reaffirmed an article published by the journal Pharmacie et de Chimie (Guibourt, 1849b). There are records that Mexico exported chia to the USA in 1872 (Garcia, 1880). According to Flowers (1882), at this time the chia seed was sold at an exorbitant price because its production was not possible in the USA. He reported that in this country the chia crop was unknown and often is replaced by psyllium (Plantago psyllium L.), possessing similar properties to chia (Urbina, 1887). In 1982, Maisch (1882) wrote the first extensive paper about the use of chia in food and medicine. Similar to Subeiran (1887), he concluded that chia should be studied in the medical field. In Mexico, Urbina (1887) published a paper to prove that chia did not grow in Spain. Similarly, De la Llave (1833), suggested changing its scientific name to $S$. chian. He coined the Soubeiran phrase (1887) "the future will decide". He predicted the chia would be an important industrial crop. After 1890, chia production in Mexico began to increase and Garcia (1893) reported that in 1893, 138 tons were harvested, in which state of Guanajuato was the primary producer. Three years later, the Mexican National School of Agriculture and Veterinary Medicine recognized the importance of chia as an oilseed, and it was included in the same group of sesame, peanut, and flaxseed (SACC, 1896). At end of 19th century, it was grown in Jalisco, Sinaloa, Chiapas, Michoacan, and Guanajuato, Mexico (Noriega,
1898). At the beginning of the twentieth century, the Department of Agriculture of the United States (USDA) expressed interests in chia. It saved specimens of $S$. hispanica and S. tiliaefolia in their herbarium (Kearney and Gardner, 1901). Later in 1918, it also collected chia from San Luis Potosí, México, the code assigned to it in his seed inventory was 46,645 (Taylor, 1922). The USDA interest to study the chia was possibly triggered by the patented the use of chia oil as a solvent of paints by Lomanitz (1917). Between 1921 and 1922, the USDA conducted several tests to evaluate the agronomic performance of chia in agricultural areas of six states of USA (Gardner, 1922). However, the results disillusioned people, because in almost all locations the chia crop did not bloom and neither produce seed. The first official record associated with the commercial production of chia appeared in 1932. In that year, the Ministry of agriculture of Mexico reported that there was 38 ha cultivated with chia. On average the seed yield was $344 \mathrm{~kg} \mathrm{ha}^{-1}$, and the main producer states of chia were Jalisco, Puebla, and Guerrero (Sosa et al., 2017a). The first agronomic study of chia in Mexico was conducted by Rulfo (1937). His work showed that it was feasible to achieve yields higher than 1.0 ton $\mathrm{ha}^{-1}$ and in some locations it's possible to get two cycles per year. The first scientific evidence about the high content of PUFAs $\omega-3$ in chia was presented by Lloyd et al. (1946). However, because its importance in the human nutrition was unknown, chia continued to be seen as an exotic seed used to prepare fresh drinks, paints to decorate handcrafts, and alive pets (Small, 2011). The key step to recognize its importance occurred in 1975, when in Greenland the PUFAs $\omega-3$ essentiality on humans was discovered (Dyerberg et al., 1975). Based on this finding, nutrition guides soon recommended ingesting between 900 and 2,000 mg of PUFAs $\omega-3$ per day to prevent cardiovascular problems (Covert, 2009), and for people diagnosed with coronary arteriosus, this recommendation is key to control the disease (Lichtenstein et al., 2006). As all food sources to cover the PUFAs $\omega-3$ requirements in a diet are scarce (Menhaden fish, salmon, algae, and flaxseed), having restrictions and high cost, chia became the ideal source to meet the PUFAs $\omega-3$ requirements (di Sapio et al., 2008).

\section{Modern era (1990-2010).}

Chia crop arrived in the twenty-first century without being incorporated with the changes needed to adapt the modern era. In part, this was due the fact that it did not travel with its ancient's mate's corn, bean, cocoa, chili, pumpkin, and tomatoes; hence, it is not one of the constituents of modern diets as the others are. This explains why the chia was not known in most countries of the world. According to Sosa et al. (2016), its use was limited to regions which adopted it before the arrival of the Spaniards to America. Starting in 1990 , the chia status as a crop was changed because it demonstrated the essentiality of PUFAs $\omega-3$ in human nutrition, which renewed scientific interest in chia. This also generated the first published works reporting the importance as a source of lipids, proteins, and fiber by Weber et al. (1991). At this time researchers of USA and Argentina visited Acatic, Jalisco, México to learn the basis of agronomic management of chia. They later conducted a research project named "Northwestern Argentina Regional 
Project" (Sosa et al., 2016). The main goals of this project were to study the nutritional profile, adaptation, breeding, agronomic management and marketing of chia in different agricultural regions of Argentina as well as Peru, Colombia, Bolivia, and Ecuador (Ayerza and Coates, 2006). Within the last 22 years, the results of that project have been published, and the technology developed has been vital to promote the use and production of chia around the world (Sosa et al., 2017a). The first application to legally trade chia in Europe was made by R. Craig \& Sons in 2003. Since it was uncompleted, the procedure was taken up by Columbus Paradigm Institute S.A in 2006. Later, it was the Committee on Regulation of Food in Europe who approved it in 2009 (TCC, 2011). The EFSA (2009) did not find any record that the chia was used before 1997. Europe, in accordance with the regulation of novel foods No. 258/97, classified the chia as a novel food. Currently, the use of the chia has been approved worldwide, and its seed is consumed directly or indirectly in baked goods, cereals, dried fruit, mixed with nuts and other seeds, non-alcoholic fruit drinks, oil and flour (FSAl, 2015). In addition, it also is used as raw material in the production of supplements, nutraceuticals and cosmetics that are sold in 30 countries (Gleeson et al., 2014).

\section{Present}

\section{The Chia boom (2010 to 2017).}

In the last seven years, the importance of chia has increased immensely, after living five centuries in oblivion. Today, it is subject of intense research (Deka and Ash, 2017). There are some sources that meet the requirements of PUFAs $\omega-3$ (Menhaden fish, salmon, algae, and flax oil) (di Sapio et al., 2008). However, chia is the safest, cheapest, and the most sustainable source, as the intake of 25 to $50 \mathrm{~g} \mathrm{day}^{-1}$ is enough to meet the daily demand of PUFAs $\omega$-3 (Vuksan et al. 2007). Taking into account that chia contains a high content of PUFAs of $\omega-3$ (58-64 \% of the total lipids), proteins (16-24\%), lipids (31-35\%), and fiber (34-56\%) (Segura et al., 2014; Valdivia and Tecante, 2015), its demand has increased over $239 \%$ per year, and its sales will be $\$ 1.2$ billion dollars in 2020 (Cassiday, 2017). The importance of chia as a crop is quite high, and countries located on the template zone such as USA, Chile, Argentina, Italy, and France where the weather does not allow its cultivation, are evaluating different agronomic practices to adapt it (Sosa et al., 2017a). The main problem faced by all these countries is that chia only grows between latitudes $20^{\circ} 55^{\prime} \mathrm{N}$ and $25^{\circ} 05^{\prime}$ $\mathrm{S}$. This is partly due to that blooming requires a photoperiod less than 12.5 hours of light. Therefore, when it is established at latitudes beyond than $39^{\circ} 11^{\prime} \mathrm{S}$ (Choele Choel, Argentina) and $32^{\circ} 14^{\prime} \mathrm{N}$ (Tucson Arizona, USA), it does not produce seed because the frosts kill it (Jamboonsri et al., 2012; Sorondo, 2014). To solve this issue, some countries developed cultivars capable to bloom in locations, where the photoperiod is higher than 12.5 hours, and currently there are five varieties insensitive to photoperiod registered around the world. The first one is the Heartland variety. It was derived by mutation with gamma radiation at the Lexington University of Kentucky USA (Hildebrand et al., 2013). It is available as a white seed and black seed, and Heartland Co. has the breeding rights (Heartland, 2016). Peru registered the varieties Sahi Alba 911 and Sahi Alba
912, and Argentina patented the Alba Sahi 914 variety. Similar to the Heartland variety, all of them have intellectual protection (Vuskan et al., 2007; Sorondo, 2014). The last cultivar registered is Oruro; it was developed by the Agrofun Co. in France (Michael, 2017). Mexico and Thailand also are conducting breeding research on chia. In Jalisco Mexico, the Nutrilite Co. identified the experimental genotype named as G-39. It will be patented as the first variety of white chia with high seed yield on the world (its name will be Rehnborg) (Sosa and Ruiz, 2018). This claim is done considering that the chia varieties developed in Argentina, Peru, USA, and France do not have records to support that their yield potential has been improved. The use of varieties with photoperiod insensitivity allowed the chia production in Argentina. In four years, its planted land area changed from 100 ha in 2010 to 120,000 ha in 2014 (Sosa et al., 2017a). The adoption of chia by Argentina was so fast, that today it is the primary producer of this oilseed. A key factor in achieving this was the marketing strategy that Agrisalba S.A. implemented in 2006 to their seeds. This Peruvian company affirms that the white seed is more nutritive than the black seed, and it gave to the white chia seed the denomination of "Salba" (Vuskan, 2007). However, that was only a marketing strategy, because the results of studies that have compared the nutritional profile of both two phenotypes do not support this claim (Ayerza, 2013; Bueno et al., 2016; Cassiday, 2017). The production of chia in the USA has been very poor. Today, it is restricted to the states of Kentucky and Florida, and the yield potential is only $290 \mathrm{~kg} \mathrm{ha}^{-1}$ (Schneider, 2014). In Italy and Chile, the researchers focused to identify the best planting dates to produce chia (Amato et al., 2015; Bochicchio et al., 2015). However until 2015, the results were disappointing because the yield was low and it often does not produce seeds. Recently, Caruso et al (2018) produce chia in Italy. They used a genotype provided by the University of Kentucky USA (insensitive to photoperiod). In Chile, the results are promising. Baginsky et al. (2016) recently found that planting between January and March at Arica Chile it is possible to produce 1.3 to 2.5 ton $\mathrm{ha}^{-1}$. In the last four years, Australia has become the fifth producer of chia (Peperkamp, 2015). Currently, this country achieves the highest average of seed yield at the world ( 1.1 ton $\left.\mathrm{ha}^{-1}\right)$ and a high percentage of its production $\left(10,000\right.$ ton year $\left.{ }^{-1}\right)$ is exported to 30 countries (Gleeson et al., 2014). In tropical regions (latitude $23^{\circ} 30^{\prime} \mathrm{N}$ and S) like Jalisco Mexico, Ghana Africa, and Mymensingh, Bangladesh, it is possible to achieve high yields of chia (1.03-2.61 ton ha ${ }^{-1}$ ) (Yeboah et al., 2014; Karim et al., 2015; Sosa et al., 2017b,c). Recently, Sosa et al. (2017b) reported that in some locations of Mexico the climatic conditions allow producing two cycles per year. In both cycles it is feasible to get high productivity. To this date farmers continue producing just one cycle per year. Chia is mainly a rainy season crop (Ramirez and Lozano, 2015), therefore, Mexico is the third largest producer of chia in the world.

\section{Future}

\section{From 2017 onwards}

The tendency to increase the global consumption of chia and its use as a raw material has confirmed a 131-year-old prediction by Urbina (1887). This Mexican botanist claimed 
that it would be an important crop in the food industry. Currently, the use of chia on the human nutrition is so wide, that universities, research centers and private companies are developing technology to exploit it as raw material of PUFAs $\omega-3$, protein and fiber in beverages, food supplements, processed foods and cosmetics (Sosa et al., 2017a). As result of this, the chia crop is extending faster around the world, and today, Purechia (2013), the leading company in the chia production is producing chia in 29 countries and it distributes 36 products of chia in 30 countries. Undoubtedly, the next generation of functional foods, supplements, processed foods cosmetics will have the chia seed as their primary ingredient. In all these products the active ingredient will be either PUFAs $\omega-3$, protein, or fiber, from the seed of chia, an ancestral Mexican crop that although forgotten for more than 500 years, but has been brought back by science. Therefore, it is available again to help improving the human health around the world. In fact, Sosa et al. (2016) considered that the chia crop has been sleeping for more than 500 years. Its destiny is to become the "Sleeping Beauty" of the functional crops. OronaTamayo et al. (2016) baptized it as the golden crop of this century.

\section{References}

AFRM (Asociación Farmacéutica de la Republica de Mexico) (1846) Farmacopea Mexicana. Capital de la Republica de México, 1846, $412 \mathrm{p}$.

Amato $M$, Caruso CM, Guzzo F, Galgano F, Commisso M, Bochicchio R, Labella R, Favati F (2015) Nutritional quality of seeds and leaf metabolites of Chia (Salvia hispanica L.) from Southern Italy. European Food Research and Technology. 241(5): 615-625.

AMQP (Academia Medico Quirúrgica de Puebla) (1832). Ensayo para la materia medica Mexicana. Puebla, México, 1832, $101 \mathrm{p}$.

Ayerza R (2014) Chia flowering season prediction using day length data of 11 selected locations. Revista Industrial Agrícola de Tucumán. 91 (1): 33-35.

Ayerza R (2013) Seed composition of two chia (Salvia hispanica L.) genotypes which differ in seed color. Emir J Food Agric. 25 (7): 495-500.

Ayerza R, Coates W (2006) Chía, redescubriendo un olvidado alimento de los Aztecas. Del nuevo extremo S.A. Buenos Aires, Argentina, 2006, 205 p.

Baginsky C, Arenas J, Escobar H, Garrido M, Valero N, Tello D, Pizarro L, Valenzuela A, Morales L, Silva H (2016) Growth and yield of chia (Salvia hispanica L.) in the Mediterranean and desert climates of Chile. Chilean J Agric Res. 76 (3); 255-264.

Bochicchio R, Philips TD, Lovelli S, Labella R, Galgano F, Di Marisco A, Perniola M, Amato M (2015) Innovative crop productions for healthy food: the case of chia (Salvia hispanica L.). In: A. Vastola (ed.). The sustainability of agrofood and natural resource systems in the Mediterranean basin. Springer-Verlag, Berlin, Germany, p. 29-45.

Bueno M, González M, Quiroga M, Severin C, Busilacchi H (2016) Caracterización de semillas blancas y negras de Salvia hispanica L. (Lamiaceae). Agromensajes. 46: 1-7.

Bueno BI (2010) El lienzo de Tlaxcala y su lenguaje interno. Anales del Museo de América. 18: 56-77.
Cahill JP (2003) Ethnobotany of chia, Salvia hispanica L. (Lamiaceae). Econ Bot. 57: 604-618.

Caruso MC, Favati F, Di Cairano M, Galgano F, Labella R, Scarpa T, Condelli N (2018) Shelf-life evaluation and nutraceutical properties of chia seeds from a recent longday flowering genotype cultivated in Mediterranean area. Food Sci Technol. 87: 400-405.

Cassiday L (2017) Chia: superfood or superfat. INFORM. 28 (1): 6-13.

Covert L (2009) Wellness Food Europe. Omega-3. EPA/DHA: The most pressing nutritional deficiency?.April/May. 2024. https://smartypantsvitamins.com/wpcontent/uploads/2010/07/omega_oils.pdf.

CRN (Council for Responsible Nutrition) (2014) Who takes Omega-3s?.

https://www.crnusa.org/CRNconsumerssurvey/2014.

de Agredos PML, Manzanilla RL (2016) Corporate Paint and Ancient Pharmaceutical Mixtures fromTeotihuacan: the Teopancazco Neighborhood Center. Int J Pharmacovigilance. 1 (1): 1-11.

de Falco B, Amato M, Lanzzoti V (2017) Chia seed products: and overview. Phytochem Rev. 16(4): 745-760.

Deka R, Das A (2017) Advances in chia seed research. Adv Biotechnol Microbiol. 5 (2): 1-3.

de la Llave P (1833) Sobre una nueva especie diferente de Salvia. Registro Trimestre: 441-448.

di Sapio O, Bueno M, Busilacchi H, Severin C (2008) Chía: importante antioxidante vegetal. Agromensajes de la Facultad. 56: 11-13.

Dubernard CJ (1991) Códices de Cuernavaca y unos títulos de sus pueblos. Porrúa, DF México, 1991, 396 p.

Dyerberg J, Bang OH, Hjorne H (1975) Fatty acid composition of the plasma lipids in Greenland skimos. Am J Clin Nutr. 28: 958-996.

EFSA (European Food Safety Authority) (2009) Opinion on the safety of 'chia seeds (Salvia hispanica L.) and ground whole chia seeds' as a food ingredient. EFSA Journal. 996: 1-26.

Farfán A (1610) Tratado breve de medicina y de todas las enfermedades. Imprenta Geronymo Balli. México, México. 1610, $261 \mathrm{p}$.

Flowers H (1882) Chia seed. Am J Pharm. 54: 227-229.

FSAI (Food Safety Authority of Ireland) (2015) Safety Assessment of Chia Seed (Extension of use). 2015, 5 p. https://www.fsai.ie/uploadedFiles/Science and_Health/N ovel_Foods/Applications/2015\%20Chia\%20Seed\%20exten sion\%20of\%20use.pdf.

Garcia CA (1893) México its trade, industries and resources. Office of Department of Foment, Colonization and Industry. México, México. 1893, 436 p.

Garcia T (1880) Memoria del hacienda y crédito público del quincuagésimo tercer año económico. Imprenta Francisco Diaz de León. México, México. 1878, 984 p.

Gardner AH (1922) Report of the scientific section: report on experimental plantations of chia in the United States during 1921. Paint Manufacturers Association of the US. Circular. 140: 93-99.

Gerhard P (1986) Geografía histórica de la nueva España (1519-1821). UNAM. D.F. México, 1986, 134 p.

Gleeson T, Agbenyegah B, Deards B, Leith R, Mifsud C, Mobsby D, Murray C (2014) Northern Australia food and fiber supply chains - commodity market analysis, Appendix 4.1 of the Northern Australia: Food and Fiber Supply Chain 
Study Project Report, CSIRO\&ABARES, Australia, August. CC BY 3.0. 2014, 136 p.

Guibourt G (1849a). Histoire naturelle des drogues simples ou cours d'histoire naturelle professé a l'Ecole de Pharmacie de Paris. 4e édition. Tome second. 562 p. http://www.biusante.parisdescartes.fr/histoire/medica/re sultats/?cote=pharma_011498x02\&do=pdf.

Guibourt G (1849b) Semence de chia. J Pharm Chimie. 3 (15) : 51-54.

Gutiérrez TR, Ramírez VLM, Vega LS, Fontecha J, Rodríguez ML, Escobar MA (2014) Contenido de ácidos grasos en semillas de chía cultivada en cuatro estados de México. Revista Cubana de Plantas Medicinales. 19: 199-207.

Haugen DJ (2009) Borrowed borrowings: Nahuatl loan words in english. LEXIS J English Lexicology. 3: 63-106

Heartland Chia (2016) Chia grown, harvested and processed in the USA for total identity preservation. http://www.heartlandchia.com/.

Hernández BJE, León JV (1994) Neglected crops: 1492 from a different perspective. Plant production and Protection series no 26. FAO. Rome, Italy. 1994, 341 p.

Hildebrand D, Jamboonsri W, Phillips DT (2013) Early flowering chia and uses thereof. United States Patent Application Publication US2013/0007909 A1.

Jamboonsri W. Phillips DT, Geneve LR, Cahill PJ, Hildebrand FD (2012) Extending the range of and ancient crop (Salvia hispanica L.) -a new omega3 source. Genet Resour Crop Evol. 59: 171-178.

Karim M, Fuzzaman A, Hossain A (2015) Effect of planting time on the growth and yield of chia (Salvia hispanica L.). Asian J Med Biol Res. 1(3):502-507.

Kearney HT, Gardner DF (1901) Report on a botanical survey of the dismal swamp region. Contributions from the United States national herbarium. 5 (6): 321-550.

León N (1895) Catalogo bibliográfico, biográfico y critica de autores y escritos referentes a vegetales de México y sus aplicaciones desde la conquista hasta el presente. Biblioteca Botánico Mexicana. Secretaria de Fomento. Republica de México. 1895, 372 p.

Lichtenstein AH, Appel $L$, Brands M, et al (2006) Diet and lifestyle recommendations. A scientific statement from the American Heart Association Nutrition Committee. Circulation. 114: 82-96.

Linneo C (1753) Species Plantarum Sections I-III. 127 p. www.gutenberg.org.

Lloyd RW, Donde M, Palma F (1946) Aceite de chía (Salvia hispanica). Boletín del Instituto de Química de la UNAM. 2: 51-56.

Lomanitz S (1917) Vegetable drying oil. Patent number 1 244, 521. United States Patent Office.

López MLS, García NG, Ibarra GNB (2012) El maíz (Zea mays L.) y la cultura Maya. BIOtecnia 14 (3): 3-8.

Lopez AR (2010) Crafting Mexico, Intellectuals, artisans, and the state after the revolution. Duke University Press. London, England. $347 \mathrm{p}$.

Macías GJ (2009) Escuinapa. Ediciones Bicentenario. Culiacán Sinaloa, México. 2009, $338 \mathrm{p}$.

Maisch MJ (1882) On chia and allied species of Salvia. Am J Pharm. 54: 229- 234.

Mapes SEC (2017) Amaranthus spp. Planta originaria de Mexico. AAPAUNAM Academia de Ciencia y Cultura. 217222.
Michael A (2017) First chia cultivated in France. Organic Wellness News. Spring: 1-9.

Mohd AN, Yeap SK, Ho WY, Beh BK, Tan SW, Tan SG (2012) The promising future of chia, Salvia hispanica L. J Biomed Biotechnol. 10.1155/2012 /171956.

Morales PP, Cienfuegos AE, Manzanilla RL, Otero TJF (2012) Estudio de la paleodieta empleando isótopos de los elementos carbono, oxígeno y nitrógeno en restos humanos y de fauna encontrados en el barrio teotihuacano de Teopancazo. In: Manzanilla RL (ed.), Estudios arqueométricos del centro de barrio de Teopancazco en Teotihuacan. Instituto de Investigaciones Antropológicas-UNAM. DF, México. Pp. 347-424.

Noriega E (1898) Geografía de la república Mexicana. Librería de lavdadech. bouret. México. 1898, 543 p.

Orona-Tamayo D, Valverde EM, Paredes LO (2016) Chia-The new golden seed for the 21st century: Nutraceutical properties and technological uses. In: Sustainable Protein Sources. S. Nadathur, Janitha P. D. Wanasundara and L. Scanlin. Chapter 17. Elsevier. Pp 265281.

Peperkamp M (2015) CBI Tailored Intelligence: chia from Bolivia 'a modern super seed in a classic pork cycle?. CBI Ministry of Foreign Affairs. The Hague, Netherlands. 2015, $16 \mathrm{p}$.

Purechia (2013) Rich Source of omega-3, protein, fiber \& antioxidants. Next Big Thing in Food. www.purechia.co.

Ramirez JJ, Lozano CGM (2015) Potential for growing Salvia hispanica L. areas under rainfed conditions of México. Agric Sci. 6: 1048-1057.

Román S, Ojeda GC, Panduro A (2013) Genética y evolución de la alimentación de la población en México. Rev Endocrinol Nutr. 21 (1): 42-51.

Rosenblat A (1945) La población indígena de América desde 1492 hasta la actualidad. Instituto de Cultura Española. Buenos Aires Argentina. 1945, 79 p.

Rulfo JM (1937) La chía. Agricultura. 1:28-37.

Sandoval ORM, Paredes LO (2013) Isolation and Characterization of proteins from chia seeds (Salvia hispanica L.). J Agric Food Chem. 63: 193-201.

Segura CRM, Ciau SN, Orozco dRG, Chel GL, Betancur AD (2014) Physicochemical caracterización of chia (Salvia hispanica L.) seed oil from Yucatán, México. Agric Sci. 5: 220-226.

Silveira CM, Salas MdIM (2014) Chemical characterization of chia (Salvia hispanica L.) for use in food products. J Food Nutr Res. 2: 263-269.

Schneider G (2014) Kentucky firm first to grow chia seed in U.S. USA Today. 9:28 pm EDT. October, 22, 2014. http://www.usatoday.com/story/news/nation/2014/10/2 2/kentucky-firm-first-to-grow-chia-seeds-in-us/17750971/. Small E (2011) Blossoming treasures of diversity. 34. ChiaNot just a pet. Biodiversity 12: 49-56.

Sociedad Anónima de Concursos en Coyoacán (SACC). 1896. Reseña del primero y segundo concursos de ganadería celebrados en enero y octubre de 1895 en la villa de Coyoacán. Oficina Tip. de la Secretaría de Fomento. México, México.

Sorondo A (2014) Chia (Salvia hispanica L.) variety Sahi Alba 914. Unites States Patent Application Publication. US 2014/0325694-A1. 
Sosa BA and Ruiz IG (2018) Inadequate nitrogen fertilization: main cause of the low seed yield on the chia crop (Salvia hispanica L.). BJSTR 2 (1): 1-2.

Sosa BA, Ruiz-lbarra G, Robles-de la Torre RR, GordilloSobrino G, Sharma M, Liu X (2017 a) La chía mexicana (Salvia hispanica L.): su historia e importancia como cultivo mundial. IX Congreso Nacional de Agricultura Sostenible. In: R. Jarquin-Galvez y A. Huerta-de la Peña (Eds.). La agricultura sostenible como base para los agronegocios. Primera edición. SOMAS. Pp. 1504-1555.

Sosa BA, Ruiz-lbarra G, Gordillo-Sobrino G, West H, Sharma S, Liu X, Robles-de la Torre RR (2017b) Fecha de siembra: un método para evadir el ataque de Diabrotica speciosa Germar (Coleoptera: Chrysomelidae) y aumentar el rendimiento de semilla en chía (Salvia hispanica L.). Entomología Mexicana. 4: 277-284.

Sosa BA, Ruiz-Ibarra G, Gordillo-Sobrino G, Sharma M, Liu X, Robles-de la Torre RR (2017c) Respuesta de cuatro cultivares de chía (Salvia hispanica L.) a la fertilización nitrogenada en el Petacal Jalisco México. Informaciones Agronómicas Hispanoamérica. 28: 8-13.

Sosa BA, Ruiz IG (2016) Será Diabrotica speciosa germar, 1824 (Coleoptera: Chrysomelidae) una plaga de importancia económica para la producción de chía (Salvia hispanica L.) en México?. Entomología Mexicana. 3: 269274.

Sosa A, Ruiz G, Rana J, Gordillo G, West H, Sharma M, Liu X, Robles dITRR (2016) Chia crop (Salvia hispanica L.): its history and importance as a source of polyunsaturated fatty acids omega-3 around the world: a review. J Crop Res Fert. 1: 104: 1-9.

Soubeiran L (1887) Etude de la semence de chia. J Pharmacie et de Chimie. 5(15):260-265.

Taylor AW (1922) Inventory of seed and plants imported by the office of foreign seed and plant introduction during the period from April 1 to June 20, 1917. USDA, 1922, $1266 \mathrm{p}$.

The Chia Company (TCC) (2011) Application for the authorization of chia seed from Salvia hispanica L. for consumption as a food and as an ingredient in additional food groups. 2011, $72 \mathrm{p}$.
Tibon G (1982) Olinalá, un pueblo tolteca en las montañas de Guerrero. Editorial Posada. D.F., México. 138 p.

Ullah R, Nadeem M, Khalique A, Imran M, Mehmood S, Javid A, Hussain J (2015) Nutritional and therapeutic perspectives of chia (Salvia hispanica L.): a review. J Food Sci Technol. 53 (4): 1750-1758.

Urbina M (1887) La chía y sus aplicaciones. La Naturaleza. Sociedad Mexicana de Historia Natural 1: 27-36.

Valdivia LAM, Tecante A (2015) Chia (Salvia hispanica): A review of native Mexican seed and its nutritional and functional properties. Adv Food Nutr Res. 75: 53-75.

Vázquez-Alonso TM, Bye R, López-Mata L, Pulido-Salas PTM, McClung deTE, Koch DS (2014) Etnobotánica de la cultura Teotihuacana. Bot Sci. 92 (4): 563-574

von Baeyer, E (2010) The development and history of horticulture. Encyclopedia of Life Support Systems, 2010, $25 \mathrm{p}$.

Vuksan V, Whitman D, Sievenpiper J, Jenkins A, Rogovik A, Bazinet R, Vidgen E, Hanna A. (2007) Supplementation of conventional therapy with the novel grain Salba (Salvia hispanica L.) improves major and emerging cardiovascular risk factors in type 2 diabetes. Diabetes Care. 30: 28042810.

Weber WC, Gentry HS, Kohlhepp AE, McCrohan RP (1991) The nutritional and chemical evaluation of chia seeds. J Ecol Food Nutr. 26: 119-125.

Yeboah S, Owusu DE, Lamptey JNL, Mochiah MB, Lamptey S, Oteng DP, Adama I, Appiah KZ, Agyeman K (2014) Influence of planting methods and density of performance of chia (Salvia hispanica L.) and its suitability as an oilseed plant. Agric Sci. 2:14-26. 